\title{
The analysis of zoobenthos quantitative indicators of the Argun River
}

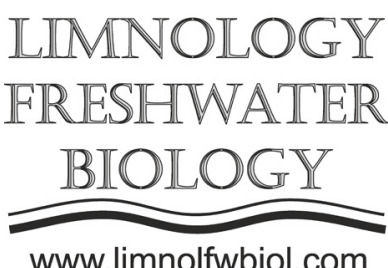

\author{
Kazykina S.M., ${ }^{1,2}$ \\ ${ }^{1}$ Eastern Branch of the Russian Research Institute for the Integrated Use and Protection of Water Resources, murskaya Street, 15, \\ Chita, 672039. \\ ${ }^{2}$ Transbaikal State University, Alexandro-Zavodskaya Street, 30, Chita, 672039
}

\begin{abstract}
Argun River basin belongs to the Upper Amur basin. It is a tributary of the first order of the Amur River, and belongs to transboundary water bodies. The paper provides data on the zoobenthos quantitative characteristics of Argun River in June and August 2016. In the zoobenthos Ephemeroptera, Trichoptera, Chironomidae, Oligochaeta, and Simulidae communities dominated. The abundance of zoobenthos varied from 0.025 to 4.942 thousand ind. $/ \mathrm{m}^{2}$, the biomass varied from 0.032 to $24.105 \mathrm{~g} / \mathrm{m}^{2}$.
\end{abstract}

Keywords: Organisms of zoobenthos, benthic fauna, abundance, biomass, groups

\section{Introduction}

The Argun River belongs to transboundary water bodies (within China it is called the Hailar River). The total length of the river is $1620 \mathrm{~km}$. At the 669th kilometer, Argun River enters the Russian Federation and further is the natural border line between Russia and China. Argun River is $951 \mathrm{~km}$ long within the Russian territory. The banks of the channel and the floodplain in the upper section of the river are mainly composed of easily eroded sandy-silty soils, the bottom of the channel is sandy-silty or sandy-pebble, in some areas it is pebble-gravel. In the lower section, the bottom of the channel is sandy-pebble, in some places it is laid out by a boulder-pebble blind area. The width of the river main channel increases downstream. The main source of water inflow is summer rains (Resursy..., 1966).

In river ecosystems, communities of aquatic organisms are indicators of ongoing processes in a water body. These indicators can be used to judge the quality of the environment, its self-cleaning ability, as well as fish productivity. Representatives of the benthic fauna, which have existed for a long time, make it possible to use their characteristics for assessing forecasts and modeling the ongoing processes.

\section{Materials and methods}

The collection of material from benthic invertebrates was carried out in June and August 2016 in the upper section of the Argun River within the Trans-Baikal Territory at the following stations: 1 - Molokanka gauging station, 2 - $200 \mathrm{~m}$ below the
Molokanka gauging station, 3 - Sredneargunsk village, 4 - Kailastui village, 5 - Kapcegaituy village, 6 - Kuti village, 7 - Starotsuruhaytui village, 8 - Novotsuruhaytui village.

At each station, the coastal zone of the observation section was surveyed. Quantitative samples of benthic invertebrates were taken on rocky ground using a standard Levanidov bentometer (Levanidov, 1977) with a capture area of $0.16 \mathrm{~m}^{2}$ in five replicates. Also, in our research we used the Schroeder-Zhadin method by collecting organisms from stones and taking into account their area (Zhadin, 1960). On silty-sandy soils, samples were taken with a Petersen bottom grab with a capture area of $0.025 \mathrm{~m}^{2}$ (Rukovodstvo..., 1983).

\section{Results and discussion}

As a result of processing the benthic fauna of the Argun River within the studied areas in 2016, 180 taxa of different systematic levels were identified. These taxa belong to six classes - Bivalvia, Gastropoda, Clitellata, Arachnidae, Nematoda, Insecta. The most diverse class of insects is represented, in which nine orders were identified: Megaloptera, Plecoptera, Ephemeroptera, Trichoptera, Coleoptera, Heteroptera, Odonta, Lepidoptera, and Diptera (Kazykina, 2018).

In June 2016, the number of zoobenthos varied from 0.053 to 4.166 thousand ind. $/ \mathrm{m}^{2}$. At the same time, mayflies, chironomids, caddisflies and oligochaetes dominated among the groups. The maximum number was recorded at the station of Kuti village -4.166 thousand ind. $/ \mathrm{m}^{2}$, with a predominance

*Corresponding author.

E-mail address: rumkazsv@mail.ru (S.M. Kazykina) 
of mayflies $84 \%$, and also in the area of the Molokanka gauging station - 2.866 thousand ind $/ \mathrm{m}^{2}$, where the predominant groups were mayflies (35\%), chironomids (25\%), caddisflies (19\%), oligochaetes (15\%). Basically, for the studied areas, a sandy-silty biocenosis was observed, which was characterized by a low species diversity. The biomass of benthic fauna varied from 0.066 to $24.105 \mathrm{~g} / \mathrm{m}^{2}$, excluding mollusks and caddisflies (in accordance with the methodology). Mayflies up to $60 \%$, caddisflies up to $60 \%$, and leeches up to $80 \%$ were the predominant groups in terms of biomass. At the same time, the maximum biomass was also noted for the abundance at the station of Kuti village, where up to $60 \%$ of the biomass were mayflies.

In August 2016, the number of zoobenthos varied from 0.025 to 4.942 thousand ind. $/ \mathrm{m}^{2}$. At the same time, caddisflies, chironomids, and mayflies dominated among the groups. The maximum number was noted at the Molokanka gauging station - 4.942 thousand ind. $/ \mathrm{m}^{2}$, where the dominant groups were caddisflies (67\%), oligochaetes (18\%), chironomids (8\%), mayflies (7\%). The biomass of benthic fauna varied from 0.032 to $3.260 \mathrm{~g} / \mathrm{m}^{2}$. The predominant groups by biomass were caddisflies up to $90 \%$, mayflies up to $72 \%$, and chironomids up to $28 \%$. At the same time, the maximum biomass was noted at the Starotsuruhaytui village $3.270 \mathrm{~g} / \mathrm{m}^{2}$, the main part of which is made up of large forms of dragonflies $75 \%$ and oligochaetes $22 \%$, as well as at the station near the Molokanka gauging station $1.138 \mathrm{~g} / \mathrm{m}^{2}$, where up to $67 \%$ biomass was caddisflies. It was noted that several dozen empty shells of large bivalve mollusks from 7 to $25 \mathrm{~cm}$ in size belonging to the family Unionidae were found on the banks of the Argun River near the Starotsuruhaytui village.

\section{Conclusions}

Thus, the basis of the zoobenthos structure of the Argun River was formed by the species assigned to the widespread eurytopic and eurythermal species. The high biomass values in June are due to the last stages of development of amphibiotic insects. In general, in terms of quantitative indicators, the values of the abundance and biomass of benthic fauna were low. A significant decrease in quantitative indicators was noted in the areas of the Sredneargunsk village, Kapcegaytui village and Novotsuruhaytui village.

\section{Acknowledgments}

The author expresses sincere gratitude to the staff of the Eastern Branch of RosNIIVKh for help in collecting the material, K.A. Kurganovich for help in translation the text, as well as to the specialists of the Federal Scientific Center for Biodiversity of Terrestrial Biota of East Asia FEB RAS - E.A. Makarchenko, T.M. Tiunova, V.A. Teslenko, O. V. Zorina, who assisted in the identification of species.

\section{References}

Kazykina S.M. Analysis of the species diversity of the Argun River in 2016. 2018. In: II International Scientific and Practical Conference "Water Resources and Water Use", pp. 97-104. (in Russian)

Levanidov V.Ya. 1977. Biomass and structure of benthic biocenoses of the Kedrovaya River. In: Presnovodnaya fauna zapovednika "Kedrovaya pad" [Freshwater fauna of the "Kedrovaya Pad"' Nature Reserve]. Vladivostok, pp. 126-158. (in Russian)

Resursy poverkhnostnykh vod SSSR. Gidrologicheskaya izuchennost' [USSR surface water resources. Hydrological knowledge]. V. 18. Dal'niy vostok [Far East]. Issue 1. Amur [Amur]. 1966. Leningrad: Gidrometeoizdat. (in Russian)

Rukovodstvo po metodam gidrobiologicheskogo analiza poverkhnostnykh vod i donnykh otlozheniy [Guidelines for methods of hydrobiological analysis of surface waters and bottom sediments]. 1983. In: Abakumov V.A. (Ed.), Leningrad: Gidrometeoizdat. (in Russian)

Zhadin V.I. 1960. Metody gidrobiologicheskogo issledovaniya [Methods of hydrobiological research]. Moscow: Vysshaya Shkola. (in Russian) 